\title{
OLAHRAGA, PENUAAN, DAN PENYAKIT- PENYAKIT YANG MENYERTAINYA
}

Oleh: Panggung Sutapa

Dosen Jurusan Pendidikan Kesehatan dan Rekreasi FIK UNY

\section{Abstrak}

Kecepatan penuaan pada seseorang bergantung pada genetik (keturunan), maupun faktor lingkungan dan gaya hidup. Banyak upaya yang ditempuh untuk menghindari penuaan secara dini karena dampak dari adanya penuaan memunculkan perubahan-perubahan baik secara anatomis maupun fisiologis.

Perubahan secara anatomis meliputi, perubahan pada jantung, otak, paru-paru, ginjal, otot, dan tulang. Perubahanperubahan anatomis berdampak pada perubahan secara fisiologis yang akhirnya berdampak pada penurunan produktivitas, angka harapan hidup (life expectancy) menjadi lebih kecil dan jangka lama hidup menjadi pendek (life span).

Salah satu alternatif untuk meningkatkan produktivitas dan meningkatkan angka harapan hidup dapat ditempuh dengan melakukan olahraga dengan memperhatikan kaidahkaidah yaitu frekuensi, lama dan beban latihan sesuai umur dan kondisi.

Kata kunci: olahraga, penuaan, penyakit.

Pateghitusingt Vol. I, No. 2, Oktober 2005: 154-165. 
Penuaan pada seseorang merupakan proses alami yang tidak dapat dicegah maupun dihindari, upaya yang dapat dilakukan mungkin hanya dalam bentuk memperlambat, penuaan berjalan beriring dengan bertambahnya usia. Penuaan yang datangnya lebih dini (premature aging) dapat terjadi pada seseorang yang disebabkan oleh banyak faktor, namun secara umum dapat dikelompokkan menjadi yaitu intrinsik dan ekstrinsik. Faktor intrinsik dapat berupa kelainan genetis dan penyimpangan ungkapan informasi genetika, sedangkan faktor ekstrinsik dapat dari penyakit infeksi, malnutrisi maupun masalah-masalah sosial ekonomi.

Kadang-kadang penampilan seseorang tidak dapat ditaksir umurnya, ada seseorang yang baru berumur 35 tahun sudah kelihatan tua, sedangkan ada pula seseorang yang sudah beumur 45 tahun masih kelihatan muda. Penuaan yang datang lebih dini dan juga penampilan yang lebih tua daripada umur akan menyebabkan produktivitas menurun, nilai angka harapan hidup (life expectancy) menjadi lebih kecil, dan jangka lama hidup menjadi pendek (life span).

Banyak upaya dapat dilakukan oleh seseorang untuk menghindari terjadinya penuaan secara dini dan terhindar dari penyakit-penyakit akibat perubahan anatomis, yang berdampak pada perubahan-perubahan fungsi fisiologis. Salah satu upaya yang dapat dilakukan adalah olahraga. Permasalahannya sekarang adalah olahraga yang bagaimana yang cocok untuk para GLAMUR (golongan lanjut umur) sehingga akan sangat membantu dalam mewujudkan impian hidup ceria di usia senja dan membantu dalam mempertahankan produktivitas serta meningkatkan nilai angka harapan hidup meningkat.

\section{GEJALA PROSES PENUAAN}

Tidak dapat dihindari lagi, proses penuaan akan terjadi pada setiap orang. Proses penuaan menyangkut penurunan fungsi organ-organ dalam termasuk paru dan jantung. Bertambah umur berarti bertambah lama pula masa kerja paru, jantung, dan pembuluh-pembuluh darahnya. Hal ini menyebabkan kekakuan dan elastisitas menjadi menurun terlebih bagi para perokok atau para pekerja tempat-tempat yang udaranya terkena polusi akan terjadi pembengkaan (emphysema). Menurut Sadoso Sumosardjuno (2002: 
15) fenomena olahraga merupakan kebalikan dari latihan-latihan olahraga. Olahraga dalam waktu yang panjang berpengaruh sangat positif pada kesehatan

Penuaan merupakan proses terjadinya perubahan anatomis. Menurut Budiarto (1998: 10) peruhan-perubahan tersebut sampai pada tingkat sel dan faktor penentu utama terletak pada inti sel. Di sisi lain menurut Askandar Tjokropranolo (1988: 13) berpendapat bahwa salah satu penurunan kesehatan pada golongan lanjut umur (glamur) adalah menurunnya sekresi hormon atau menurunnya kepekaan reseptor pada organ. Menurut Soekarman (1988: 29) pengaturan proses penuaan terdapat di dalam inti sel (nucleus). Nucleus pada orang tua lebih banyak mengandung vacuole dibanding pada nucleus orang muda dan dalam percobaannya didapatkan bukti bahwa dengan menukar nucleus pada sel muda ke dalam cytoplasma sel tua nucleus sel muda lebih mampu memperbanyak diri.

Menurut Emma Wirakusumah (2000: 7) pemicu proses penuaan sangat dipengaruhi adanya faktor: (1) Genetika yang merupakan faktor bawaan yang bebeda pada setiap individu. Faktor ini yang mempengaruhi perbedaan efek menua pada setiap individu, (2) Faktor lingkungan dan gaya hidup. Faktor ini berkaitan dengan diet (asupan zat gizi), kebiasaan merokok, minum-minumam beralkohol. Secara rinci faktor-faktor yang berpengaruh dan risiko yang menyertai terlihat dalam uraian selanjutnya.

\section{PERUBAHAN-PERUBAHAN AKIBAT TERJADINYA PROSES PENUAAN DAN PENYAKIT YANG MENYERTAINYA}

Menurut Mc Ardle (1981: 426-429) perubahan akibat proses penuaan meliputi: (1) kecepatan penghantaran saraf, (2) kapasitas pernapasan maksimal, dan (3) curah jantung. Dampak adanya penurunan penghantaran kecepatan saraf (nerve conduction velocity) ini adalah pada penurunan waktu reaksi, waktu reaksi lebih lama/lambat sehingga dalam mereaksikan suatu rangsang lebih lama. Penurunan kapasitas pernapasan maksimal (PKM) sangat erat hubungannya dengan peruhan bentuk togok. Misalnya tubuh menjadi kiposis, penurunan elastisitas paru dan penurunan kapilaria dalam paru.

Wizentediant Vol. I, No. 2, Oktober 2005: 154-165. 


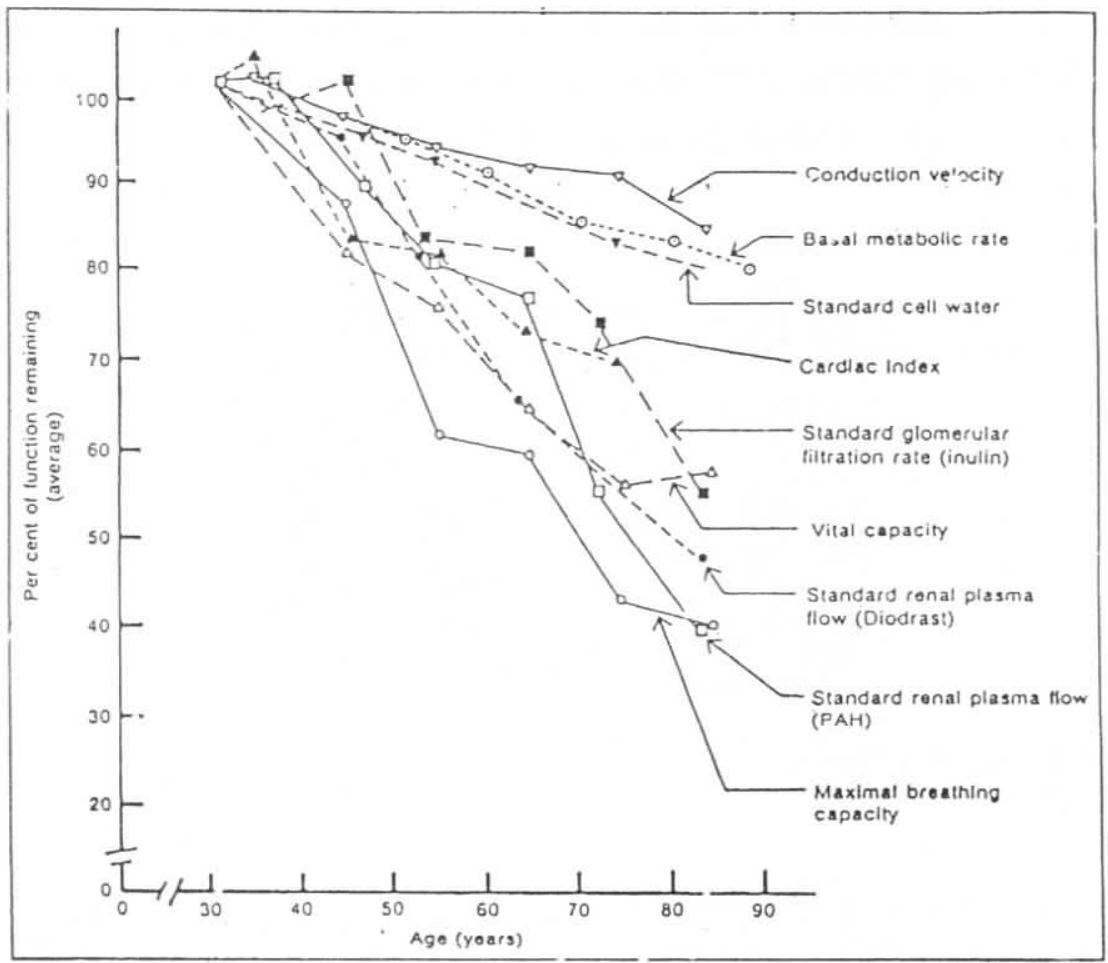

Gambar 1: Penurunan Bebagai Macam Kapasitas Fungsional Tubuh (MC Ardle 1981: 487)

Paru dapat dikembang kempiskan oleh: (1) gerakan turun dan naik diafragma untuk memperbesar atau memperkecil rongga dada, (2) elevasi dan depresi iga-iga untuk meningkatkan dan menurunkan diameter anteroposterior rongga dada. Kontraksi diafragma menarik batas bawah rongga dada sehingga meningkatkan panjang longitudinalnya. Elevasi bagian anterior rangka dada menyebabkan peningkatan ukuran anteroposterior dengan mekanisme selama ekspirasi iga-iga ditarik ke arah bawah dari kolumna spinalis. Apabila sternum diangkat ke atas, iga-iga akan mengembang lebih ke depan daripada ke bawah. Hal ini membuat diameter anteroposterior dada akan meningkat 20 persen lebih besar selama inspirasi daripada ekspirasi. Oleh karena itu otot-otot yang meninggikan rangka dada dikelompokkan sebagai otot inspirasi dan otot yang menurunkan rangka dada sebagai otot ekspirasi. Bentuk tubuh yang kiposis akan berdampak 
pada ketidakmampuan secara maksimal mengembangkan rangka dada dan ditambah dengan menurunnya otot-otot pernapasan akan makin menambah berkurangnya kemampuan pernapasan maksimal.

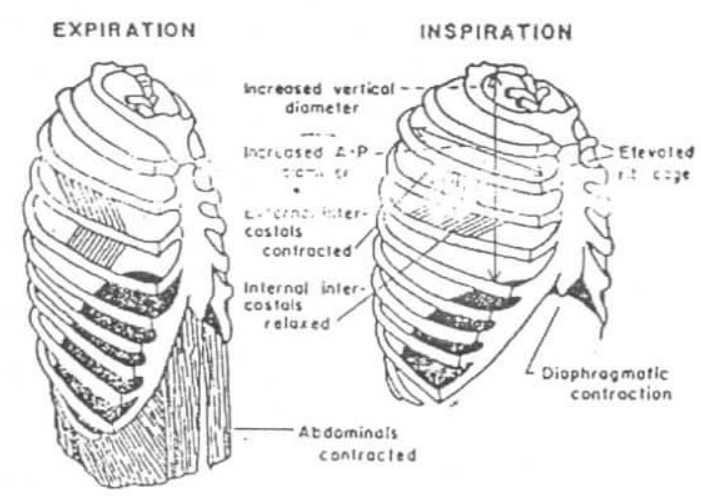

Gambar 2: Elevasi dan Depresi Iga-iga

Menurut Guyton (1988: 60) faktor yang dapat menurunkan kapasitas fungsi pernapasan paru, yaitu: (1) berkurangnya luas membran respirasi, (2) meningkatnya tebal membran respirasi, yaitu yang disebut blok alveolocapiler, dan (3) rasio ventilasi perfusi yang abnormal dalam beberapa bagian paru-paru.

Berkurangnya luas membran respirasi. Penyakit atau kelainan yang menurunkan luas membran respirasi termasuk pengangkatan satu bagian atau semua bagian dari satu paru-paru, kerusakan paru-paru karena tuberkulosis, kanker, dan emfisema yang menyebabkan kerusakan septum alveolus secara berangsur-angsur, keadaan akut yang mengisi alveolus dengan cairan atau menghalangi udara berhubungan langsung dengan membran alveolus, seperti pneumonia, udem paru-paru, dan atelektasis dapat menurunkan luas permukaan membran respirasi.

Meningkatnya tebal membran respirasi - Blok Alveolokapiler. Penyebab akut tersering dari meningkatnya tebal membran resipirasi adalah . udem paru-paru yang disebabkan oleh kegagalan jantung kiri atau pneumonia, tetapi, skoliosis, tuberkulosis, dan banyak keadaan fibrotik lain dapat menyebabkan penumpukan jaringan fibrosa secara progresif di dalam

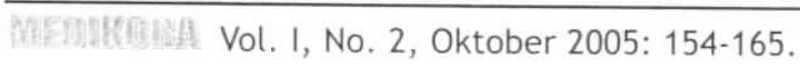


ruang interstisial di antara membran alveolus dan membran kapiler paruparu. Dengan demikian, meningkatnya tebal membran respirasi biasanya disebut blok aveolokapiler, atau, kadang-kadang fibrosis interstisial. Kecepatan difusi gas melalui membran respirasi berbanding terbalik dengan jarak yang harus ditempuh oleh gas tersebut, dengan demikian blok alveolokapiler dapat menurunkan kapasistas difusi paru-paru.

Rasio ventilasi-perfusi yang abnormal. Abnormalnya rasio ventilasiperfusi paru-paru dapat menyebabkan penurunan kapasitas difusi paru-paru. Hal ini merupakan salah satu kelainan yang lebih sulit dimengerti, tetapi dapat dijelaskan sebagai berikut: jika aliran darah banyak ke alveolus di blokir total atau sebagaian, ventilasi olveolus ini sedikit atau tidak bermanfaat dalam aerasi darah, dan sekalipun begitu, alveolus ini mengurangi ventilasi alveolus normal. Demikian pula, apabila aliran darah normal tetapi ventilasi banyak alveolus diblokir, darah yang mengalir melalui alveolus tersebut tidak dapat diaerasikan. Oleh karena itu aerasi darah yang optimal memerlukan distribusi ventilasi dan aliran darah yang optimal yang kirakira proporsional terhadap tiap-tiap alveolus. Rasio ventilasi-perfusi terjadi pada orang yang berdiri tegak, karena bagian bawah paru-paru jauh lebih baik diperfusi dengan darah dari pada bagian atas. Selama gerak badan aliran darah di bagian atas paru-paru sangat meningkat; oleh karena itu, apabila selama gerak badan berat diperlukan pertukaran gas maksimum melalui membran-membran paru-paru, rasio ventilasi-perfusi menjadi hampir optimal.

Pada penyakit paru-paru rasio ventilasi-perfusi dalam berbagai bagian paru-paru dapat menjadi abnormal sekali, sehingga kapasitas difusi paruparu dapat berkurang menjadi sekecil seperlima normal. Penurunan ini sering terjadi meskipun ventilasi total dan perfusi total paru-paru sama sekali normal. Rasio ventilasi-perfusi abnormal karena buruknya ventilasi banyak alveolus, darah yang memperfusi alveolus ini tidak menjadi teraerasikan. Oleh karena itu, darah tersebut dikatakan dijalan pintas melalui paru-paru yaitu, ia mengalir melalui paru-paru tanpa berhubungan dengan alveolus fungsional. Kelainan tersebut disebabkan oleh buruknya aliran darah ke alveolus yang diventilasi dengan normal, ventilasi alveolus ini sia-sia, oleh karena itu, ruang mati fisiologis paru-paru meningkat. 
Menurut Jatno (1988: 53) perubahan-perubahan akibat dari adanya proses penuaan meliputi: (1) jantung, (2) Otak, (3) paru-paru, (4) Ginjal, (5) otot, dan (6) tulang. Perubahan fisiologis pada manula pada dasarnya mengikuti proses alami dari proses penuaan. Dengan bertambahnya umur terjadi perubahan patologik pada berbagai organ jantung yang dinding ventrikel kiri membesar, cardiac ouṭ put menurun, denyut nadi maksimal menurun dan tekanan darah meningkat. Akibat perubahan tersebut adalah tubuh tidak mampu merespons secara baik terhadap stres tertentu. Pada sistem kardiovaskuler, aterosklerosis merupakan perubahan yang sangat mencolok, sehingga terjadi peningkatan tahanan pada pembuluh darah arteri sistemik maupun pulmonal. Curah jantung akan menurun baik pada waktu istirahat maupun pada saat berolahraga sebagai akibat menurunnya stroke volume dan heart rate dan keadaan tersebut disebabkan oleh adanya: (1) complien daya regang otot jantung menurun, (2) meningkatnya tahanan pembulih darah, dan (3) kontraksi otot jantung menjadi lebih lambat.

Perubahan pada otak. Berat otak selama kehidupan akan mengalami penurunan berat antara 10 sampai 12 persen. Dalam keadaan normal terdapat macam sel penghasil hormon di hipofisis anterior yaitu sel asidofil menghasilkan hormon pertumbuhan (GH) dan prolaktin, sel kromofob menghasilkan prolaktin dan ACTH serta sel basofil menghasilkan gonadotropin, ACTH, dan TSH. Hipofisis posterior pada nuklei supraoptikus dan paraventrikuler menghasilkan vasopresin dan antidiuretik hormon $(\mathrm{ADH})$ serta oksitosin. Perubahan pada paru, pada proses penuaan volume residual paru meningkat, kapasitas vital menurun, kapasitas pernapasan maksimal menurun dan juga kemungkinan terjadi atrofi pada paru serta terjadi penurunan kapilaria dalam paru. Menurut Brooks (1981: 687) perubahan anatomis dan hubungannya dengan kemunduran fungsi fisiologis akibat ada proses penuaan digambarkan dalam bentuk bagan secara rinci sebagai berikut:

1. Mineral tulang menurun hal ini berdampak secara signifikan pada terjadinya osteoporosis dan risiko terhadap patah tulang meningkat.

2. Komposisi tubuh dan struktur lemak tubuh meningkat, dampak dari hal tersebut adalah meningkatnya risiko timbulnya berbagai macam penyakit, seperti tekanan darah tinggi, diabetes militus, dan aterosklerosis.

Vol. I, No. 2, Oktober 2005: 154-165. 
3. Massa otot, ukuran motor unit, dan nilai potensial aksi menurun, terjadinya penurunan ini berdampak pada penurunan kekuatan maupun power.

4. Jumlah kapiler paru menurun hal ini berpengaruh pada penurunan ventilasi yaitu banyaknya udara yang dikeluar masukkan dalam paru.

5. Elastisitas dan sruktur ukuran alveolus menurun dengan demikian akan terjadi penurunan kapasitas difusi dan meningkatnya ruang mati.

6. Elastisitas pembuluh darah, volume sedenyut dan perbandingan serabut kapiler menurun sehingga berpengaruh pada penurunan aliran darah ke otot, menurunnya stroke volume dan cardiac output serta meningkatnya resistensi periteral, dan tekanan darah.

Proses penuaan akan mengakibatkan penurunan dalam berbagai hal, antara lain:

1. Kekuatan otot

Pada proses penuaan terjadi berkurang ukuran ototnya. Berkurangnya ukuran otot ini disebabkan berkurangnya jumlah protein dan juga karena berkurangnya jumlah dan besar serabut-serabut otot. Penurunan otot terjadi secara bertahap dari umur 35-45 tahun, namun demukian penurunan kekuatan otot pada usia 60 tahun tidak sampai $20 \%$.

2. Metabolisme basal

Dengan bertambahnya umur ada kecenderungan bertambah lemak tubuh, hal ini biasanya disebabkan aktivitas fisik berkurang sehingga kalori yang masuk lebih banyak daripada yang digunakan.Di samping itu, kemampuan untuk memobilisasi asam lemak yang tertimbun sebagai jaringan lemak (corpus adiposum) juga akan menurun, sehingga asam lemak yang dibakar sangat berkurang. Bersamaan dengan kenaikan atau bertambahnya jumlah lemak (lean body weight) berat badan tanpa lemak menurun Penurunan ini sejajar dengan menurunnya massa otot, disamping itu terjadi pula penurunan kadar kalsium dan fosfor dari tulang. Penurunan berat badan tanpa lemak sebenarnya dapat dihambat dengan memperbaiki pola makan dan berolahraga secara teratur. Laju metabolisme basal (BMR $=$ Basal Metabolic Rate) secara bertahap menurun dengan bertambahnya usia.

Bertambahnya usia tidak dapat dipungkiri membawa perubahanperubahan ke arah kemunduran, baik secara fisik maupun mental. Penyebab

Olahraga, Penuaan, dan Penyakit- penyakit yang Menyertainya (Panggung Sutapa) 
timbulnya penyakit pada manula sulit didiagnosis karena penyakitnya tersembunyi (occult), sehingga diperlukan waktu yang agak lama untuk mengadakan observasi dan pengamatan secara cermat terhadap tanda dan gejala penyakitnya. Secara umum pada proses penuaan penyakit yang sering muncul yaitu:

1. Penyakit radang sendi (artritis). Peningkatan usia akan membawa perubahan pada semua organ dan jaringan tubuh termasuk pada sistem musculosleletal dan jaringan lain. Artritis merupakan penyakit yang menyerang tulang, sendi maupun jaringan di sekitar sendi.

2. Hipertensi. Penyakit ini akan meningkat sejalan dengan meningkatnya usia, hipertensi pada lansia sering disertai dengan kelainan cardiovasculer seperti angina pektoralis, infark jantung, stroke, dan kelainan pembuluh darah. Hipertensi pada lansia dapat dibedakan menjadi dua yaitu hipertensi dengan kondisi tekanan sistolik sama atau lebih besar dari $140 \mathrm{mmHg}$ atau tekanan diastolik sama atau lebih besar dari $90 \mathrm{mmHg}$ dan hipertensi terisolasi, dengan kondisi sistolik lebih besar dari 160 $\mathrm{mmHg}$ dan tekanan diastolik lebih rendah dari $90 \mathrm{mmHg}$.

3. Jantung koroner. Penyakit ini lebih cenderung disebabkan oleh pola hidup yang tidak sehat, pola makan, merokok, kurang olahraga, kolesterol, darah tinggi (hepercolesterolaemia) obesitas.

4. Diabetes militus. Penyakit ini timbul akibat sistem metabolisme hormonal di samping adanya faktor keturunan dan pola makan.

5. Stroke. Penyakit ini akibat peredaran darah di otak mengalami gangguan. Stroke dapat menyebabkan terjadinya kelumpuhan, gangguan penglihatan, penurunan fungsi pendengaran daya ingat dan kemampuan dalam berkomunikasi.

6. Osteoporosis. Bertambahnya usia dapat menurunkan daya serap kalsium oleh tubuh sehingga zat yang dibutuhkan oleh tulang sangat berkurang hal ini akan berdampak pada mudah patahnya tulang

7. Kanker. Sel kanker timbul akibat kerusakan DNA, kerusakan ini sendiri akibat radikal bebas, virus, radiasi dan zat kimia yang bersifat karsinogenik, di samping terjadinya penurunan kekebalan tubuh sehingga terjadi gangguan perbaikan sel.

Vol. I, No. 2, Oktober 2005: 154-165. 


\section{OLAHRAGA PADA USIA TUA}

Mengenai panjangnya umur seseorang tidak dapat diperdebatkan, diirikan tiap orang, namun tiap orang pasti mendambakan umur panjang penuh dengan vitalitas dan masih kelihatan muda dibanding dengan usianya. Oleh karena itu, muncul usaha untuk mencegah terjadinya proses degeneratif atau proses penuaan yang datang lebih dini. Menjadi tua adalah proses alami, fungsi anatomis maupun fisiologis mulai menurun atau berkurang secara perlahan-lahan. Semua orang adalah calon manula apabila tidak ada kecelakan yang menyebabkan terjadinya kematian. Tidak ada orang yang dapat mencegah terjadinya penuaan dan kematian karena bagaimanapun hidup ini secara perlahan namun pasti akan menghadapi kematian. Adanya anggapan orang yang gemar olahraga pasti memiliki tubuh yang sehat dan bugar, namun hal ini tidak semuanya benar. Untuk menjaga kondisi tubuh , seseorang harus melakukan olahraga secara teratur dan dosis yang tepat akan menjamin keselamatan organ-organ tubuh. Jika dosis latihan kurang tidak banyak manfaat dan jika dosis olahraga berlebihan akan berakibat kurang baik dan bahkan dapat berakibat fatal. Pada orang yang sudah lanjut umur justru ada kontraindikasi untuk menjalankan olahraga, di antaranya kegagalan jantung kongestif, pulmonary hipertension, dan valvular disease.

Menurut Soekarman(1988: 35) olahraga yang teratur dan terukur bagi para orang usia lanjut akan sangat bermanfaatdi antaranya: (1) Memelihara kapasitas jantung dan pembuluh darah. Maksimal konsumsi $\mathrm{O}_{2}$ menurun sebanyak $20 \%$ dari umur 20 sampai 65 tahun. Penurunan ini disebabkan oleh turunnya denyut jantung maksimal(maximal heart rate), isi sekuncup (struke volume), dan perbedaan kadar $\mathrm{O}_{2}$ arteri-vena (Arterio venous $\mathrm{O}_{2}$ difference). Proses penuaan menyebabkan terjadinya penurunan transpot $\mathrm{O}_{2}$ maupun kemampuan sel untuk menggunakan $\mathrm{O}_{2}$. Pada orang yang sudah lanjut umur latihan ketahanan, dan meningkatkan kapasitas aerobik akan meningkatkan $\mathrm{VO}_{2}$ max sebesar $20 \%$ dari masa latihan dan di samping itu akan terjadi peningkatan sirkulasi koroner, volume jantung menjadi lebih besar sehingga isi sekuncup dan hal ini akan berdampak meningkatnya curah jantung. (2) Meningkatkan otot-otot pernapasan sehingga dapat terjadi peningkatan kapasitas pernapasan Paru-paru yang normal terdapat cadangan kapasitas yang besar untuk memenuhi ventilasi pada saat olahraga, kapasitas 
ini akan menurun pada umur 30 tahun terlebih bagi para perokok maupun orang yang mendapat polusi udara. (3) Mencegah terjadinya osteoporisis, olahraga dapat meningkatkan mineral tulang sehingga tulang menjadi lebih kuat. Osteoporosis akan berdampak mudahnya tulang patah. (4) Mencegah terjadinya kekakuan otot dengan menggerakkan pada bagian persendian dan juga penguluran degradasi serat colagen, fibrous, selaput persendian dan rusaknya selaput persendian, serta berkurangya viskositas cairan sendi dapat dikurangi. Menurut Setiono Mangunprasojo (2000: 7) olahraga untuk manula harus tepat dosis agar tidak terjadi kontraindikasi. Secara umum patokan untuk hal yang harus diperhatikan adalah denyut nadi yang terpadu sebagai berikut :

Tabel 1: D... Latihan Berdasarkan Denyut Nadi

\begin{tabular}{|c|c|}
\hline USIA & $\begin{array}{c}\text { DENYUT NADI } \\
\text { DIANJURKAN 60-80\% }\end{array}$ \\
\hline 20 & $120-160$ \\
\hline 25 & $117-156$ \\
\hline 30 & $114-152$ \\
\hline 35 & $112-150$ \\
\hline 40 & $108-150$ \\
\hline 45 & $105-140$ \\
\hline 50 & $102-136$ \\
\hline 55 & $100-132$ \\
\hline 60 & $96-128$ \\
\hline 65 & $94-124$ \\
\hline
\end{tabular}

Lebih lanjut olahraga yang banyak bermanfaat adalah jalan kaki atau yang bersifat aerobik dengan panduan beban latihan sesuai dengan frekuensi seperti tersebut di atas. 


\section{KESIMPULAN}

Proses penuaan akan selalu diikuti dengan penurunan fungsi fisiologis tubuh (jantung, paru, ginjal) yang selanjutnya berdampak pada munculnya keluhan-keluhan akibat penyakit yang menyertai. Jenis olahraga yang lebih cocok adalah olahraga jalan kaki atau olahraga yang bersifat aerobik dengan memperhatikan intensitas latihan, frekuensi latihan, dan lamanya latihan.

\section{DAFTAR PUSTAKA}

Askandar Tjokopranolo. (1988). Sistem Endokrin pada Usia Lanjut. Laboratorium UPT Penyakit Dalam. FK Unair dr. Soetomo.

Boediharto. (1988). Aspek Bio Kimia pada Proses Penuaan. Laboratoriun Bio Kimia FK. Unair Surabaya.

Brooks, G.A., Fahey, T.D. (1977). Exercise Physiology Human Bio Energetic and Its Aplication. New York.

Emma Wirakusumah. (2000). Tetap Bugar di Usia Lanjut. Cimanggis Bogor: Pustaka Pembangunan Swadaya Nusantara.

Guyton, A.C. (1976). Text Book of Medical Physiology. Saunder Company Philadelpia. Janto. (1988). Kelainan Jantung pada Usia Lanjut. Laboratorium UPF Kordiologi FK. Unair dr. Soetomo Surabaya.

Sadoso Sumosardjuno. (2002). "Sehat dan Bugar dengan Olahraga". Kompas. (19 Juni 2002).

Setiono Mangunprasojo. (2005). Olabraga Tanpa Terpaksa.Yogyakarta: Think Fresh

Soekarman. (1988). "Masalah Olahraga pada Anak". Makalah. Surabaya.

Olahraga, Penuaan, dan Penyakit- penyakit yang Menyertainya (Panggung Sutapa) 